\title{
Accuracy in dictation after improvement of reading and copying skills in a student with learning difficulties
}

\author{
Precisão em ditado após fortalecimento de \\ leitura e cópia em um escolar de risco
}

Ana Claudia Moreira Almeida VERDU ${ }^{1}$

France Matos de OLIVEIRA ${ }^{1}$

\begin{abstract}
The aim of this study was to use systematic teaching in a clinical setting using software to teach reading and writing in one boy with learning difficulties and obtain accurate performance in dictation. In the pre-test, the student showed good performance in matching-to-sample tasks (96\% in matching printed words to dictated words; $88 \%$ in matching pictures to dictated words), although he obtained a low percentage of correct answers in the dictation of constructed responses (52\%) and manuscripts (24\%). The teaching strengthened the selection of printed words matched to dictated words and copying words. The student obtained $100 \%$ correct answers in the teaching tasks. In post-tests of dictation, he obtained $100 \%$ correct answers in constructed response and 96\% correct answers in manuscripts. The results indicate that carefully teaching copying may promote accuracy in the performance of responding to minimal units in dictation tasks.
\end{abstract}

Keywords: Adolescent; Avoidance learning; Reading; Teaching materials.

\section{Resumo}

O objetivo deste trabalho foi adotar, em condições clínicas, um ensino sistemático de leitura e escrita oferecido por um software em um adolescente com características de desempenho condizentes com dificuldades de aprendizagem a fim de que ele obtivesse desempenho preciso em ditado. No pré-teste, o aluno mostrou bom desempenho em relações que envolviam a seleção de palavras impressas diante da palavra ditada (96\%) e diante da figura (88\%), mas registrou baixa porcentagem de acertos em ditado com construção da resposta (52\%) e manuscrito (24\%). O ensino fortaleceu a seleção de palavra impressa mediante ditado e cópia da palavra impressa. O aluno obteve $100 \%$ de acertos no ensino; nos pós-testes de ditado, obteve 100\% de acertos com construção da resposta e 96\% de acertos em manuscrito. Os resultados indicam que o ensino criterioso da cópia pode favorecer a precisão no desempenho de responder a unidades mínimas em tarefas de ditado.

Palavras-chave: Adolescente; Aprendizagem da escrita; Leitura; Materiais de ensino.

\footnotetext{
$\nabla \nabla \nabla$

${ }^{1}$ Universidade Estadual Paulista Júlio de Mesquita Filho, Faculdade de Ciências, Departamento de Psicologia. Av. Luiz Edmundo Carrijo Coube, 14-01, Vargem Limpa, 17033-360, Bauru, SP, Brasil. Correspondência para/Correspondence to: A.C.M.A. VERDU. E-mail: <anaverdu@fc.unesp.br>.

Support: Rectory of University Extension of the Universidade Estadual Paulista Júlio de Mesquita Filho. Instituto Nacional de Ciência e Tecnologia sobre Comportamento, Cognição e Ensino. Conselho Nacional de Desenvolvimento Científico e Tecnológico, Process nº $573972 /$ 2008-7. Fundação de Amparo à Pesquisa do Estado de São Paulo, Process nº 2008/57705-8.
} 
Relations of equivalence area model that has been adopted in psychology with an operationalist influence to explain the emergence of novel conceptual behavior. Use of the term "equivalence" was initially proposed by Sidman (1971), who taught a boy with microcephaly to pair relations according to a model of dictated words and printed words. The boy was already able to pair dictated words with figures and name figures. The tests showed that the subject was able to pair printed words with figures and orally read these words, among other emerging relations, without the need for direct teaching.

Relations of equivalence can be established when two or more elements are interchangeable or can substitute for one another, and these different stimuli control the same behavior. The establishment of relations of equivalence can occur by learning conditional relations among stimuli. One of the procedures that is more widely used for the establishment of conditional relations has been the pairing model, which consists of presenting a stimulus with a model function and two or more stimuli with the function of choice, in which the subject's response is the choice of a stimulus that is arbitrarily related to the model. After learning at least two conditional relations with a common element, a third conditional relation can emerge without direct teaching by extension of its functions. According to this model, if a dictated word is related to a figure and if the same dictated word is related to a printed word, then one can obtain a relation between the figure and printed word without previous teaching (Sidman, 1994).

The model of relations of equivalence has been used by many researchers in the field of learning, with the goal of finding more effective teaching procedures, given that its use results in saving time.

Considering the variations in Matching-toSample (MTS) procedures, arbitrary relations among stimuli (dictated words, figures, and printed words) can be taught in different ways and minimize errors, such as teaching by exclusion, fading, and Constructed Response Matching-to-Sample

26 (CRMTS). Teaching by exclusion designates not only a single repertoire but also a set of conditions that allow the occurrence of the repertoire. The set of conditions establishes an audio-visual baseline between a dictated word and printed word. If the new word is dictated and a new printed word is presented as a comparison, then the resulting repertoire involves the participant's tendency to exclude the known printed word and select the new one. The term "exclusion" was used for the first time by Dixon (1977), and the literature has shown that exclusion is important for the acquisition of new vocabulary by children and allows rapid learning without errors (Almeida-Verdu et al., 2008; Bagaiolo \& Micheletto, 2004; Domeniconi, Costa, Souza, \& Rose, 2007; Wilkinson, Dube, \& Mcllvane, 2008).

The teaching of conditional relations with the use of fading consists of the successive and gradual alteration of a dimension of the stimulus, such as intensity, color, or shape, by increasing it (fading in) or decreasing it (fading out). This alteration produces an extension of the control of a stimulus that strongly controlled one response over another. When a relation between a dictated word and a printed word is taught, one of the possible variations caused by fading can be an overlap of the dictated word and corresponding printed word, thus transforming this stimulus into a composite stimulus. In the first trials, the selection of the printed word as the comparison is a function of the physical similarity to the printed word, a component of the model. In successive trials, the component of the model printed word vanishes through fading. The control exerted by the printed word is gradually extended to the dictated word, making the attempt purely audio-visual. One of the first procedures in the field was performed by Terrace (1963), and it has been used to teach conditional relations in different populations (Almeida-Verdu et al., 2008; Bagaiolo \& Micheletto, 2004).

Teaching by exclusion and teaching by fading, although they result in greater precision of the repertoire of stimulus selection under control of the relation between a dictated word and a printed word (a type of reading), do not warrant 
either the emergence or precision of the repertoire of writing the word, which requires composition.

One way to establish a repertoire of composition is using CRMTS, in which the target response is not the selection of a stimulus with multiple components (a printed word) but rather the construction of a response from the selection of these components (letters that when put together form the presented stimulus model). The response to be constructed can be a function of a dictated word (a typical dictation task) or a written word (a copying task). The desired subproduct of this type of procedure is the subject's behavioral control over minimal units that compose the word and, depending on the teaching organization, the emergence of new words from the recombination of units from the teaching words. One of the first proposals for the CRMTS procedure was presented by Dube, McDonald, Mcllvane, and Mackay (1991). The procedure has been adopted for diverse studies on the conditions involved in the establishment of writing and spelling (Rose, Souza, \& Hanna, 2002; Souza, Hanna, Rose, Melo, \& Quintero, 2004; Souza, Goyos, Silvares, \& Saunders, 2007).

Studies that adopted these teaching procedures in simple or combined ways demonstrated their effectiveness in the acquisition of reading and writing repertoires, especially with a minimal number of trials and errors (Amorese \& Haydu, 2010). In a review of the literature on the equivalence of stimuli in Brazil from 1997 to 2007, de Paula and Haydu (2010) reported many advances in teaching technology but few publications in national journals, especially in the educational context.

Some recent initiatives have sought to teach reading and writing through teaching technology derived from the paradigm of relations of equivalence. Its application has occurred in lesscontrolled environments, such as schools and homes. Studies verified the feasibility of its collective application when implemented by teachers (Amorese \& Haydu, 2010; Peres \& Carrara, 2004) or individually (Afonso, 2011; Freitas, 2008; Reis,
Souza, \& Rose, 2009) through theuse of software managed by parents, teachers, or therapists.

Among the possibilities of individual application, one can cite ProgLeit ${ }^{\circledR}$ software (Rosa Filho, Souza, Rose, Fonseca, \& Hanna, 1998), which has the goal of teaching elementary reading and writing repertoiresby adopting different learning procedures without errors. In addition to teaching relations of equivalence among dictated and written words and figures, the program presents syllabic training that teaches relations among graphemes and phonemes, thus allowing the recombination of generalization in reading new words. Currently, a large number of studies have used this software in a variety of participants, including children enrolled in regular schools (Reis et al., 2009), children with intellectual deficiencies (Afonso, 2011; Freitas, 2008), children with dyslexia (Araújo, 2007), and illiterate adults (Melchiori, Souza, \& Rose, 2000).

Considering the possibilities of using ProgLeit ${ }^{\circledast}$, the objective of the present study was to adopt the systematic teaching provided by the software to teach reading and writing in a clinical setting with an adolescent who had performance characteristics that were consistent with learning difficulties. Our goal was to establish writing performance under dictation.

\section{Method}

This was single case study based on consultations with an adolescent who had difficulties following the regular elementary school curriculum. Nine 50-min sessions were conducted, during which we performed diagnostic evaluations of the subject's needs, conducted intervention sessions with ProgLeit ${ }^{\circledR}$ software, and provided feedback to legal guardians or teachers.

\section{Case}

Cadu (a fictitious name) was an 11-year old boy who attended the fourth year of elementary school in a municipal school in São Paulo state, 
Brazil, when he was referred to the Clinical Psychology School by the local unit of Associação de Pais e Amigos dos Excepcionais (APAE, Association of Parents and Friends of Exceptional).

Brief history of the subject: He was under the care of his grandmother who lived in a rural area. The family had a history of intellectual deficiency. For this reason, his grandmother enrolled him in APAE. During the screening process in APAE, the grandmother was told that the child did not have the typical characteristics of intellectual deficiency and was then referred to the Clinical Psychology School, indicating the need for psychological evaluation. Cadu presented typical development during his childhood. However, since beginning formal schooling, the teachers indicated his difficulties performing tasks, lack of participation in classes, and learning delays compared with his peers. He always attended a regular school and did not repeat any year but presented difficulties in several disciplines. He received criticism about his performance from the teachers. His behavior in the school was considered passive and introspective, with little participation. During the school semester in which he received care from the Clinical Psychology School, he participated in extra classes in addition to his normal activities in the school.

Major complaints: The complaints were presented by his grandmother and school. The school stated that Cadu had learning difficulties because he did not follow the disciplines similarly to the other studentsand could not read (reported by hisgrandmother). The grandmother was afraid that the boy may have a type of mental disorder or disease.

Materials: We first performed an interview with the grandmother for data collectionto establish the therapeutic relation and intervention. The grandmother approved of Cadu's participation in the activities and signed a consent form provided by the institution. To better characterize the school's complaints and initial performance, we used the Wechsler Intelligence Scale for Children - WISC III (Wechsler, 1997) and Test of School Performance -

28 TSP (Stein, 1994).
With the goal of precisely probing the performance complaints and problems writing words, the boy was subjected to a pretest using Aprendendo a Ler e Escrever em Pequenos Passos (ProgLeit ${ }^{\circledR}$ ) software provided by the Núcleo de Estudos sobre Comportamento, Cognição e Ensino (ECCE) of the Universidade Federal de São Carlos.The program uses figures, written words (visual stimuli), and dictated words (auditory stimuli) to assess language difficulties: maçã (apple), folha (leaf), elefante (elephant), placa (board), golfinho (dolphin), coruja (owl), algema (handcuff), leão (lion), fazenda (farm), jarra (jar), barco (boat), escada (stairs), vassoura (broom), saia (skirt), sol (sun), mochila (backpack), abacaxi (pineapple), igreja (church), rosa (rose), doce (sweet), foguete (roquet), etiqueta (tag), exército (army), and girasol (sunflower). The stimuli were shownon a computer screen or presented through the computer's speaker. The steps of evaluation and teaching presented tasks that involved relations between events using pairing procedures. The solicited responses included the selection of stimuli (MTS) and eliciting responses (CRMTS).

Procedure: A computer controlled the program's tasks. The program displayed two types of tasks that could be used for evaluation (without programmed consequences for correct responses or errors) orteaching (with programmed consequences for correct responses or errors).

Pre-test: The program presented tasks of selecting stimuli by pairingreading, dictation, and copying, subdivided into 24 -trial blocks. The pairing activities consisted of presenting a stimulus model and three comparison stimuli from which the participant had to choose a comparison stimulus that was related to the model. The programmed tasks were dictated word-figure (AB), dictated wordprinted word ( $A C)$, figure-printed word $(B C)$, and printed word-figure (CB). The vocalization activities consisted of naming the figures $(\mathrm{BD})$ and reading the printed words (CD). The dictation tasks consisted of dictation by composition with letters/syllables that formed a word (AE) and manuscript dictation (AF). The copying tasks followed the same division (copy by composition with the letter that formed the word 
[CE] and manuscript copying [CF]). Table 1 illustrates the steps of the design adopted by ProgLeit ${ }^{\circledR}$.

Teaching: Teaching consisted of arranging teaching contingencies of coherent relations with the dictated exigencies that were performed specifically for this test. The responses under dictation (AF) could be described as an emission of motor behavior, in which the product (grapheme) exactly correspondedto each unit of the dictated word (phonemes). For the subject to be able to write under dictation, it was necessary that he presented a motor behavior that was under the control of each unit of a written word (CF) and that he related the written word to the dictated word according to the conventions of its verbal community (AC). The functions that the written word exerted on the written word were transferred to a dictated wordby stimulus equivalence. Thus, among all of the activities that ProgLeit ${ }^{\oplus}$ provides, we selected those that taught relations of copying with construction (CE) and manuscriptdictation (CF) and the selection of printed words from dictated words $(A C)$ and a dictationtest (AE and AF).

\section{Teaching 1: Teaching the selection of printed words after dictated words and teaching copying}

The arrangement of the tasks began with exposure to 24-trial blocks of teaching the dictated word-printed word relation (AC), with one for each word. The word was dictated through the computer's speaker, and the requested response was to select the printed word that was related to the model. The block of trials was based onthe procedure of exclusion, in which the selected printed word in the actual trial was supposed to be the one that should be rejected in the next block because the dictated word was also altered. Correct responses and errors had different consequences. For errors, repetition of the block was programmed, whereas $100 \%$ correct responses allowed the participant to be exposed to the block of copies. The block of copies presented 24 trials to teach the relation $C E$ that began with presentation of the printed word on the computer screen. The participant was asked to copy the word by clicking the letters that were randomly distributed on the computer screen and construct a response (CE). For $100 \%$ correct responses, the participant was tested for dictation. In cases of errors, repetition of the copy block was programmed.

\section{Post-test 1: Dictation evaluation}

Dictation was evaluated always when teaching the set of relations between dictated words, printed words, and copying was concluded. In the condition of construction of a response (AE),

Table 1

Steps of the selected ProgLeit ${ }^{\circledR}$ design for the student's teaching and testing at Bauru (SP), 2007

\begin{tabular}{|c|c|c|c|c|}
\hline Phase & Relations & Type of performance & Number of trials & Goal \\
\hline \multirow{8}{*}{ Pre-test } & Dictated word - figure (AB) & Selection & 24 & \multirow{8}{*}{ Teaching 1} \\
\hline & Written word - reading (CD) & Vocalization & 24 & \\
\hline & Dictated word - written word (AC) & Selection & 24 & \\
\hline & Figure - written word (BC) & Selection & 24 & \\
\hline & Written word - figure (CB) & Selection & 24 & \\
\hline & Figure-naming (BD) & Vocalization & 24 & \\
\hline & Dictated word - construction (AE) & Composition & 24 & \\
\hline & Dictated word - manuscript (AF) & Composition & 24 & \\
\hline \multirow{2}{*}{ Teaching 1} & Dictated word - printed word (AC) & Selection & 24 & \multirow{2}{*}{ Post-test 1} \\
\hline & Printed word - construction (CE) & Composition & 24 & \\
\hline Post-test 1 & Dictated word - construction (AE) & Composition & 24 & Teaching 2 \\
\hline \multirow{2}{*}{ Teaching 2} & Dictated word - Printed word (AC) & Selection & 24 & \multirow{2}{*}{ Post-test 2} \\
\hline & Printed word - manuscript (CF) & Composition & 24 & \\
\hline Post-test 2 & Dictated word - manuscript (AF) & Composition & 24 & End \\
\hline
\end{tabular}


a word was dictated through the computer's speaker. The letters that composed that word were displayed on the screen in random order, and the participant had to select the order that was consistent with the dictated word. In the evaluation of dictation, there were no programmed consequences for correct responses or errors. However, in the case of correct responses, the session was terminated. In the case of errors, resumption of the teaching conditions was programmed.

\section{Teaching 2 and Post-test 2}

This teaching phase involved review of the selections that were taught for written words after dictated words (AC), manuscript copying (CF), and tests of manuscript dictation (AF), with the same teaching characteristics as the prior tests (Table 1).

\section{Results and Discussion}

\section{Diagnostic evaluation}

On the WISC-III, Cadu obtained a borderline general classification of Mental Deficiency $(\mathrm{IQ}=72)$. When evaluating the area of execution, the classification was Mild Mental Deficiency (IQ=68). In the verbal area, a borderline classification of Mental Deficiency was made $(\mathrm{IQ}=79)$. On the TSP, Cadu also presented poor performance, obtainingan inferior total classification (raw score $=65$; the expected score for his age is 115). The classification was also inferior in the sub-itens writing (raw score $=3$; the expected score for his age is 28), arithmetic (raw score=10; the expected score for his age is 20), and reading (raw score $=52$; the expected score for his age is 66).

Cadu presented adaptive behaviors that were adequate for his age and performed with good skill daily social activities, such as catching the bus by himself to go to school, presenting self-cleaning and self-care behaviors, shopping, changing, having friends, and playing in a group. Based on these observations and his general borderline classification on the WISC, Cadu did not meet the criteria for a diagnosis of intellectual deficiency (American Association on Mental Retardation, 2002). According with the American Association on Mental Retardation (2002), for a person to meet the diagnostic criteria for intellectual deficiency, he has to present a general intelligence quotient that is inferior to two mean standard deviations anda deficit in at least two areas of adaptive behavior, and this situation has to appear before the age of 18 years. The results of the TSP, together with the lack of complaints with regard to sensorial deficiencies, indicate that Cadu's performance met the diagnostic criteria for learning difficulties (National Joint Committee on Learning Disabilities, 1994, p.65).

Learning disabilities is a general term that refers to a heterogeneous group of disorders manifested by significant difficulties in the acquisition and use of listening, speaking, reading, writing, reasoning, or mathematical abilities... Even though a learning disability may occur concomitantly with other handicapping conditions (for example, sensory impairment, mental retardation, social and emotional disturbance) or environmental influences (such as cultural differences, insufficient/inappropriate instruction, psychogenic factors), it is not the result of those conditions or influences.

\section{Pre-test}

The necessity of academic learning was best detected by ProgLeit ${ }^{\circledR}$, the results of which are presented on the right in Figure 1 (Pre-test).

Cadu showed a high percentage of correct responses $(70-100 \%)$ in the selection of relations $(B C, C B, A C, C C)$ and vocalizationof figure (BD) and written word (CD) stimuli. The results that showed $<50 \%$ correct responses were obtained in dictation, either manuscript (AF) or composition (AE). Thus, although Cadu could read, he could not write with precision. 


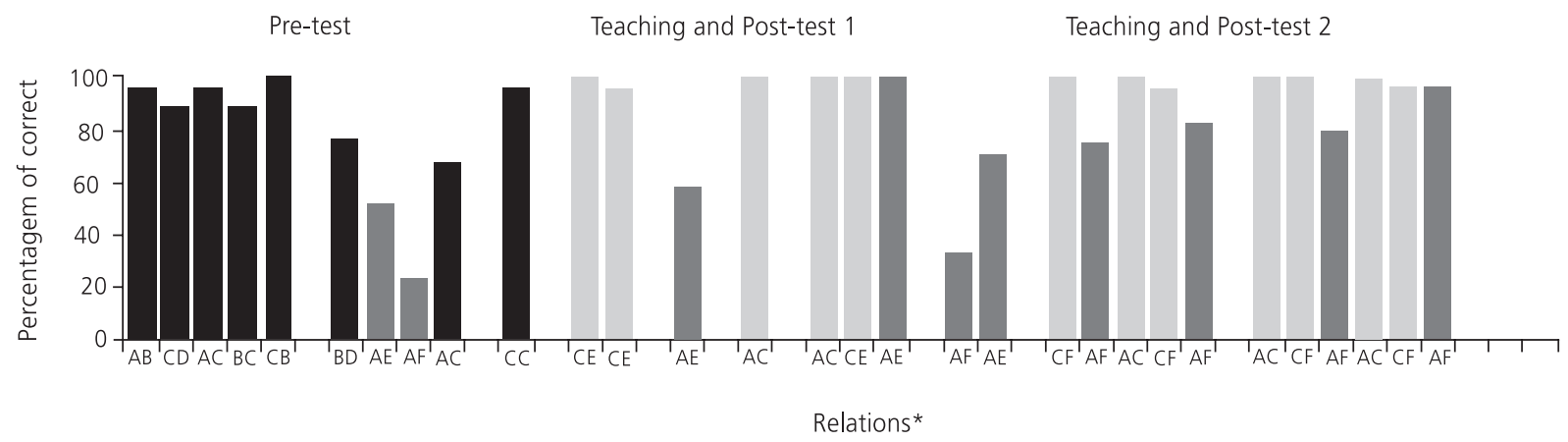

Figure 1. Percentage of correct responses in the relations tested and taught across sessions. Black bars indicate relations tested in the Pre-test. Light gray bars represent the relations taught. Dark gray bars represent the relation of post-test dictation.

Note: * The description of the relations is provided in Table 1.

\section{Teaching}

Based on the pre-test, target relations for teaching in post-test 1 were selected. Copying by composition with a mobile alphabet (CE) was strengthened, and dictation was tested (AE). Cadu's performance was practically precise in copying, but with dictation, he obtained only $60 \%$ correct responses. This result indicates that precision in copying, although needed for good writing, was not a sufficient condition for this to occur in dictation (Rossit \& Zuliani, 2003). Therefore, two relations were strengthened ( $A C$ and $C E$ ), the nodule of which (C) favored the emergence of the dictation relation $(\mathrm{AE})$ and precise performance (100\% correct responses in all of the relations). After obtaining 100\% correct responses in dictation with anagrams (AE), manuscript dictation (AF) was tested, and performance was $<40 \%$ correct responses. Teaching and post-test 2 were then conducted. Cadu was exposed to strengthening of manuscript copying (CF), and his performance in manuscript dictation (AF) increased to $75 \%$ correct responses. After strengthening the two relations (AC and (F), the nodule of which (C) favored the emergence of the relation of manuscript dictation $(\mathrm{AF})$, performance in dictation in this modality was $85 \%$ correct responses. After two more exposures to this set of relations, performance in dictation reached $95 \%$ correct responses.

Notably, the planned teaching contingencies favored the control of the dictated word stimulus
(A) over writing by composition (E) and manuscript (F) through the common element in the printed word (C). Teaching the relation AC followed by teaching the relation CE or CF allowed extension of control of the dictated word to construct the word with letters of the alphabet (AE) or manuscript $(\mathrm{AF})$, which was Cadu's greatest difficulty.

The use of copying activities based on criteria in a coherent way with the paradigm of relations of equivalence is consistent with findings in the literature (Hanna et al., 2002; de Souza et al., 2004; Rossit \& Zuliani, 2003). Hanna et al. (2002) reported that copying improved the performance of six children in tasks of dictation, which was the focus of Cadu's intervention. This hypothesis was also based on the fact that tasks of constructing responses (CRMTS) favor the development of control of stimuli by smaller units with low indices of errors because errors are quite deleterious to performance itself.

At the end of the intervention, we contacted Cadu's teacher and provided a general framework of the teaching practices that would result in more effective learning, specifically writing under the control of a visual stimulus (CE) to expand audition (AE). We also separately provided feedback for the adolescent and his responsible guardian. For Cadu, we provided a paper with all of the words and their corresponding figures that he learned to write with dictation. For Cadu's responsible guardian, we briefly explained the interventions that were performed and ruled out the hypothesis of mental 
deficiency. We understand that this was a gain for everyone involved in this case, allowing the establishment of new relations from Cadu's new repertoire and conditions under which this repertoire could be achieved. Cadu's behavior, caretaker, and teacher function within his environment to provide hints and reinforcement for the actions of the others.

The present study also indicates that copying and responding to dictation involve similar motor responses, but are functionally different. The fact that one is established does not mean that the other also occurs (Skinner, 1957). Control by stimuli involved in copying and dictation is distinct. One requires the printed word (copying), and the other requires attention to the dictated word (dictation). However, for accurate performance in dictation to occur, both the printed word and dictated word need to be taken as equivalent (Sidman, 1994).

This case study illustrates an attempt to use teaching technologies derived from the paradigm of relations of equivalence in a clinical context. Advancements in achieving the learning criteria were significant, and the intervention duration was relatively short (1 month), given that the sessions occurred twice per week.

The present results, together with recent findings, using software and individual application (Afonso, 2011; Reis et al., 2009) or using instructional programs for teachers to apply collectively (Amorese \& Haydu, 2010; Peres \& Carrara, 2004) indicate the possibility of adapting this type of teaching procedure to teaching practices for teachers and schools. The present results also demonstratethat the adequate programming of teaching contingencies produceseffective learning for students. This case study, together with recently applied research, strengthens the argument that methods based on relations of equivalence can be used as an instructional supplement for students who present learning difficulties.

The limitations of this study include the fact that it had only one participant, and the programming of the tasks depended on knowledge and manipulation of the software. These limitations 32 have been the target of recent studies with regard to individual application (Afonso, 2011; Reis et al., 2009). The principal advantages were the subject's increase in repertoire and knowledge for both the student and the teacher with regard to the best way to learn writing. According to Stromer, Mackay, and Stoddard (1992), methods basedon a set of relations of equivalence can derive not only from teaching technology but also from evaluating whether the school's current teaching curriculum establishes the relations that are necessary for precise performance in reading and writing.

\section{References}

Afonso, P. B. (2011). Aplicação de um software de leitura e escrita por familiares de indivíduos com deficiência intelectual (Dissertação de mestrado não-publicada). Programa de Pós-Graduação em Psicologia, Universidade Federal de São Carlos.

Almeida-Verdu, A. C. M., Huziwara, E. M., de Souza, D. G, de Rose, J. C., Bevilacqua, M. C., Lopes Jr. J., et al. (2008). Relational learning in children with deafness and cochlear implants. Journal of the Experimental Analysis of Behavior, 89(3), 407-424.

American Association on Mental Retardation. (2002). Mental retardation: Definition, classification, and systems of supports. Washington, DC: Author.

Amorese, J. S., \& Haydu, V. B. (2010). Ensino e aprendizagem de leitura de palavras: contribuições da análise do comportamento. Revista Brasileira de Análise do Comportamento, 12(1-2), 197-223.

Araújo, M. W. M. (2007). Habilidades metafonológicas e desenvolvimento de leitura e escrita recombinativas em crianças com diagnóstico de dislexia (Dissertação de mestrado não-publicada). Programa de Pós-Graduação em Teoria e Pesquisa do Comportamento, Universidade Federal do Pará.

Bagaiolo, L. F., \& Micheletto, N. (2004). Fading e exclusão: aquisição de discriminações condicionais e formação de classes de estímulos equivalentes. Temas em Psicologia, 12(2), 168-185.

Dixon, L. (1977). The nature of control by spoken words over visual stimulus selection. Journal of the Experimental Analysis of Behavior, 27(3), 433-422.

Domeniconi, C., Costa, A. R. A., Souza, D. G., Rose, J. C. (2007). Responder por exclusão em crianças de 2 a 3 anos em uma situação de brincadeira. Psicologia: Reflexão e Crítica, 20(2), 3342-3350.

Dube, W. D., McDonald, S. J., Mcllvane, W. J., \& Mackay, H. A. (1991). Constructed-response matching to sample and spelling instruction. Journal of Applied Behavior Analysis, 24(2), 305-317. 
Freitas, M. C. (2008). Programação de ensino de leitura e escrita para crianças com deficiência mental (Dissertação de mestrado não-publicada). Programa de Pós-Graduação em Educação Especial, Universidade Federal de São Carlos.

Hanna, E. S., Souza, D. G., Rose, J. C., Quinteiro, R. S., Campos, S. N. M., Alves, M., et al. (2002). Aprendizagem de construção de palavras e seus efeitos sobre o desempenho em ditado: importância do repertório de entrada. Arquivos Brasileiros de Psicologia, 54(3), 255-273.

Melchiori, L. E., Souza, D. G., \& Rose, J. C. (2000). Reading, equivalence, and recombination of units: A replication with students with different learning histories. Journal of Applied Behavior Analysis, 33(4), 97-100.

National Joint Committee on Learning Disabilities. (1994). Collective perspectives on issues affecting learning disabilities. Austin, TX: PRO-ED.

Paula, J. B. C., \& Haydu, V. B. (2010). Revisão bibliográfica de pesquisas brasileiras sobre equivalência de estímulos. Psicologia: Teoria e Pesquisa, 26(2), 281-294.

Peres, E. A., \& Carrara, K. (2004). Dificuldades de leitura: aplicação da metodologia da equivalência de estímulos. Psicologia Educacional, 18, 77-94.

Reis, T. S., Souza, D. G., \& Rose, J. C. (2009). Estudos em Avaliação Educacional, 20(44), 425-450.

Rosa Filho, A. B., Souza, D. G., Rose, J. C., Fonseca, M. L., \& Hanna, E. S. (1998). Aprendendo a ler e escrever em pequenos passos: Software para pesquisa (versão 1.0). São Carlos, UFSCar, 1998.

Rose, J. C. C., Souza, D. G., \& Hanna, E. S (1996). Teaching, reading and spelling: Exclusion and stimulus equivalence. Journal of Applied Behavior Analysis, 29(4), 451-469.

Rossit, R., \& Zuliani, G. (2003). Repertórios acadêmicos básicos para pessoas com necessidades especiais. Temas em Psicologia da SBP, 11(2), 114-121.
Sidman, M. (1971). Reading and auditory-visual equivalences. Journal of Speech and Hearing Research, 14(1), 5-13.

Sidman, M. (1994). Equivalence relations and behavior: A research history. Boston, MA: Authors Cooperative.

Skinner, B. F. (1957). Verbal behavior. São Paulo: Cultrix.

Souza, S., Goyos, C., Silvares, E., \& Saunders, R, (2007). Emergent printing and spelling from CRMTS Constructed Response Matching-to Sample instruction. European Journal of Behavior Analysis, 8(1) 49-64.

Souza, D. G., Hanna, E. S., Rose, J. C., Melo, R. M., \& Quintero, R. (2004). Ensino de leitura e escrita em escolares de risco: ensino de cópia e desempenho em ditado. In E. G. Mendes, M. A. Almeida \& L. C. A. Williams (Orgs.), Temas em educação especial: avanços recentes. São Carlos: EDUFSCar.

Stein, L. M. (1994). Teste de desempenho escolar: manual para aplicação e interpretação. São Paulo: Casa do Psicólogo.

Stromer, R., Mackay, H. A., \& Stoddard, L. T. (1992). Classroom applications of stimulus equivalence technology. Journal of Behavioral Education, 2(3), 225-256.

Terrace, H. S. (1963). Errorless transfer of discrimination across two continua. Journal of the Experimental Analysis of Behavior, 6(2), 223-232.

Wechsler, D. (1997). Escala Wechsler de inteligência para crianças: manual para aplicação e avaliação. Rio de Janeiro: Cepa.

Wilkinson, K. M., Dube, W. V., \& Mcllvane, W. J. (2008). Fast mapping and exclusion (emergent matching) in developmental language, behavior analysis, and animal cognition research. Psychological Record, 48(3), 407-416.

Received on: 17/11/2012

Final version on: 29/6/2012

Approved on: 31/7/2012 
